\author{
Paweł GIL ${ }^{1}$ \\ Rafał GAŁEK ${ }^{2}$ \\ Krzysztof KIEDRZYŃSKI ${ }^{3}$ \\ Adrian KMIECIŃSKI ${ }^{4}$
}

\title{
OPERATIONAL RESEARCH OF GROUND HEAT PUMP AND PASSIVE AIR CONDITIONING
}

\begin{abstract}
This article presents a passive air conditioning system using the lower source of the ground heat pump. Passive air conditioning uses the natural cold accumulated in the ground especially in the summer season. A hydraulic diagram and the principle of passive air conditioning were presented in the text. The purpose of the measurement was to determine the cooling power, the characteristic temperatures and the soil temperature distribution at the depth of 2 meters at the ground excavated site of the spiral ground heat exchanger. Annual temperature distributions in the ground which directly affect annular cooling power were presented. Advantages and disadvantages of passive air conditioning have also been presented.
\end{abstract}

Keywords: passive air conditioning, heat pump, ground heat exchanger

\section{Introduction}

In the times of increasing environmental pollution caused by burning fossil fuels for energy production, the issue of limiting emissions of toxic components into the atmosphere seems to be particularly important. Renewable energy sources are an increasingly important part of power systems [1-14]. They usually occur in the form of centralized power plants or as distributed units near the final users. Renewable energy sources can also be joined to create hybrid systems with a high degree of reliability, ecology and economy in comparison to a single unit.

Many measurements show that the ground temperature below a certain depth remains relatively constant throughout the year; for smaller depths the temperature in the ground can be considered as quasi-constant in smaller time intervals [7-12]. This phenomenon occurs because temperature fluctuations at the ground surface are reduced as the depth of the ground increases because of high thermal

\footnotetext{
${ }^{1}$ Corresponding author/autor do korespondencji: Paweł Gil, Rzeszow University of Technology, 8 Powstańców Warszawy Ave., 35-959 Rzeszów, e-mail: gilpawel@ prz.edu.pl

2 Rafał Gałek, Rzeszow University of Technology, e-mail: rafalgalek@ prz.edu.pl

3 Krzysztof Kiedrzyński, Rzeszow University of Technology, e-mail: krzykied@prz.edu.pl

${ }^{4}$ Adrian Kmieciński, Rzeszow University of Technology, e-mail: kmiec@prz.edu.pl
} 
inertia of soil. Also, there is a time lag between temperature fluctuations at the surface and in the ground. Therefore, in summer the soil temperature at a certain depth is lower than the temperature of the air and vice versa in winter the soil temperature at a certain depth is higher than the air temperature. The difference in temperature between the outside air and soil can be utilized as a preheating means in winter and pre-cooling in summer by operating a ground heat exchanger GHE [7].

In general, the ground heat exchangers can be divided into open and closed systems. In an open system, soil may be used directly to heat or cool a medium which can be air or water. The ambient air from the external air intake passes through tubes dug in the ground and goes directly to an air-conditioned room or building. In a similar way, the ground water may be used as a cooling medium; in most cases two wells are required- one for extraction and one for injection. In a close system the medium circulates in a loop. The heat exchangers are located underground in a horizontal or vertical position.

Eicker [9] presents a passive air conditioner working in the Lamparter Company in Weilheim, Germany. The ground heat exchanger is positioned around the building and consists of two pipes of $0.35 \mathrm{~m}$ and $90 \mathrm{~m}$ in length. The pipes are laid at a mean depth of $2.80 \mathrm{~m}$. The GHE cools the fresh air supplied to the building. The annual coefficients of performance (COP) were calculated from the sum of cooling energy divided by the electrical energy consumed. The obtained COP was 50, 35 and 38 in the years 2001, 2002 and 2003. The author presents also the performance of horizontal ground brine to air heat exchanger mounted in a building in Tubingen, Germany. Five horizontal soil to brine heat exchangers with a length of $100 \mathrm{~m}$ each were installed under the ground at the depth of $1.2 \mathrm{~m}$. During hot, two week measurement period in June 2005 an average cooling power of $1.5 \mathrm{~kW}$ with a maximum of $4 \mathrm{~kW}$ was obtained. The brine pump consumed about $60 \mathrm{~W}$ and the brine to air heat exchanger fan consumed $30 \mathrm{~W}$. This results in average COP of 18.4. The average heat flux per pipe length was about $3 \mathrm{~W} / \mathrm{m}$.

Ali et al. [10] experimentally investigated two ground heat exchangers in Japan. One GHE is parallel to the ground surface and the second one is perpendicular to ground surface. The cooper tube coated with LDPE was considered as a heat exchanger material. The loop diameter is about $1 \mathrm{~m}$ and $7 \mathrm{~m}$ in length. Each GHE has $39.5 \mathrm{~m}$ in tube length. Water was considered as the heat carrier. The heat flux is a heat output per unit tube length. For short-term period up to 1 hour the heat flux reaches about $5 \mathrm{~W} / \mathrm{m}$, but for long-term operation $(96 \mathrm{~h})$ the heat flux is about $3 \mathrm{~W} / \mathrm{m}$. Naili et al. [11] presents an experimental analysis of horizontal ground heat exchanger developed in Northern Tunisia. The GHE consist of polyethylene tube with external diameter of $20 \mathrm{~mm}$ and $25 \mathrm{~m}$ in length, buried at the depth of $1 \mathrm{~m}$. Maximum heat exchange amounts about $650 \mathrm{~W}$. Heat flux per unit tube length is $26 \mathrm{~W} / \mathrm{m}$. Naili et al. [12] deals with energy and exergy analysis of the horizontal ground heat exchangers. The GHE circuit consists of $50 \mathrm{~m}$ long pipe laid out at the depth of $1 \mathrm{~m}$. The GHE was used for air conditioning room of the 
area of $12 \mathrm{~m}^{2}$. The average cooling load in July was about $670 \mathrm{~W}$ and covered $65 \%$ of its total cooling requirement. Immediately after the start the heat flux was about $38 \mathrm{~W} / \mathrm{m}$ but after 60 minutes it decreased to $26 \mathrm{~W} / \mathrm{m}$.

The purpose of the measurement is to determine the cooling power of the passive air conditioner on the base of the collected experimental data, and to present temperature distribution in the ground. Annual temperature distributions in the soil allow to estimate suitability of passive air conditioning in specific months.

\section{Experimental set-up}

The prototype passive air conditioner using the lower source of heat pump was designed and manufactured at the Department of Thermodynamics. The natural temperature difference between the soil at the depth of two meters and the laboratory room is used to operate the air conditioner. The cooler ground serves as a heat sink, while warm air in the laboratory as a source of heat. In the laboratory there is a heat pump and two hot water storage tanks, two central heating buffers and a large number of pipelines; therefore there is a high temperature in the room. Due to limited budget, it was decided to design and develop the passive air conditioning by the economic method. The heat pump in summer and especially during the holiday season practically does not work. It is a source of heat for the support of central heating in winter, as well as hot water. In summer, the hot water needs are covered by solar thermal collectors. The lower source of the heat pump is a four-loop ground spiral heat exchanger. All pipes of about $150 \mathrm{~m}$ in length are placed in the form of a spiral at the depth of $2 \mathrm{~m}$ below the ground in trenches that are $1 \mathrm{~m}$ wide and $25 \mathrm{~m}$ long (Fig. 1). A tube with an external diameter of $40 \mathrm{~mm}$ and wall thickness of $2.4 \mathrm{~mm}$ was used. All four branches of the ground heat exchanger are connected to the manifolds in the well. On the surface above the dug ground heat exchanger there is a lawn. This exchanger is located close to the L building of the Faculty of Mechanical Engineering and Aeronautics of Rzeszów University of Technology (Fig. 1). The heat carrier of the heat exchanger is a solution of $40 \%$ propylene glycol in water, hereinafter referred to as glycol, which is pumped by a WILO pump with the nominal power of $200 \mathrm{~W}$. This pump can be switched on independently of the heat pump by an external relay.

This ground heat exchanger is the lower source of the STIEBEL ELTRON WPWE heat pump installed in the same laboratory. The heat pump has the nominal heating output of $8.3 \mathrm{~kW}\left(35^{\circ} \mathrm{C} / 0^{\circ} \mathrm{C}\right)$ and a compressor of $1.9-3.5 \mathrm{~kW}$ of electric power. For cooling of warm air in the laboratory, a car radiator from Fiat Ducato with two fans was used. STOWEST fans with a diameter of $325 \mathrm{~mm}$ and the rated power of $75 \mathrm{~W}$ were used (Fig. 2). The $90 \times 42 \mathrm{~cm}$ radiator with fans was installed on a steel support structure. 

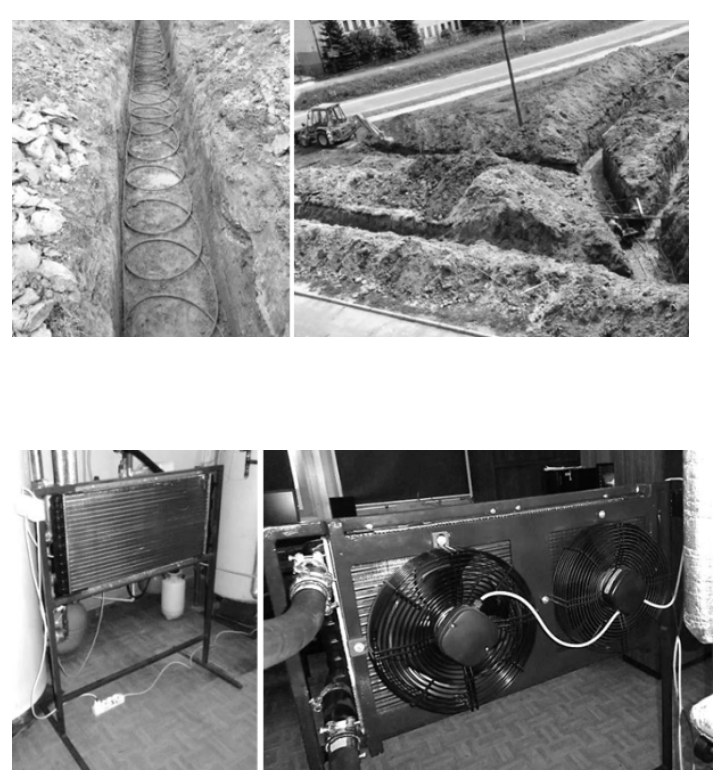

Fig. 1. Ground heat exchanger

Fig. 2. Cooler: a) front view, b) rear view

The hydraulic system with a three-way valve can work in two modes: the first one is connecting the radiator with the ground heat exchanger and the other one is connecting the radiator with the heat pump (Fig. 3). The first mode allows to receive coolness from the ground, the second mode allows to create the lower source of the heat pump from the cooler. Measurements related only to the first mode will be considered. Air conditioning was launched in May 2015. During the measurement of the cooling power of the air conditioner, the heat pump was switched off. The measuring system of the air conditioning unit consists of Pt1000 temperature sensors connected to the Keithely 3706A multimeter. Temperature sensor signal was automatically measured and converted to temperature in a program written in the LabVIEW environment. The whole temperature measurement system was calibrated. For volumetric flow measurement a flow meter was used. The pulse signal as well as the temperature were recorded in the text file at one minute intervals. The temperature distribution around the ground heat exchanger was recorded by the use of the set-up described in detail in [9]. Ground temperature sensors are 55 thermocouples of type T. The location of the thermocouples in the ground is shown in Fig. 4. The thermocouple was placed in the ground as shown in Fig. 4. Measurement of the signal from the thermocouple was carried out with a Keithley 2700 multimeter. The measurement data was automatically saved to a text file. 


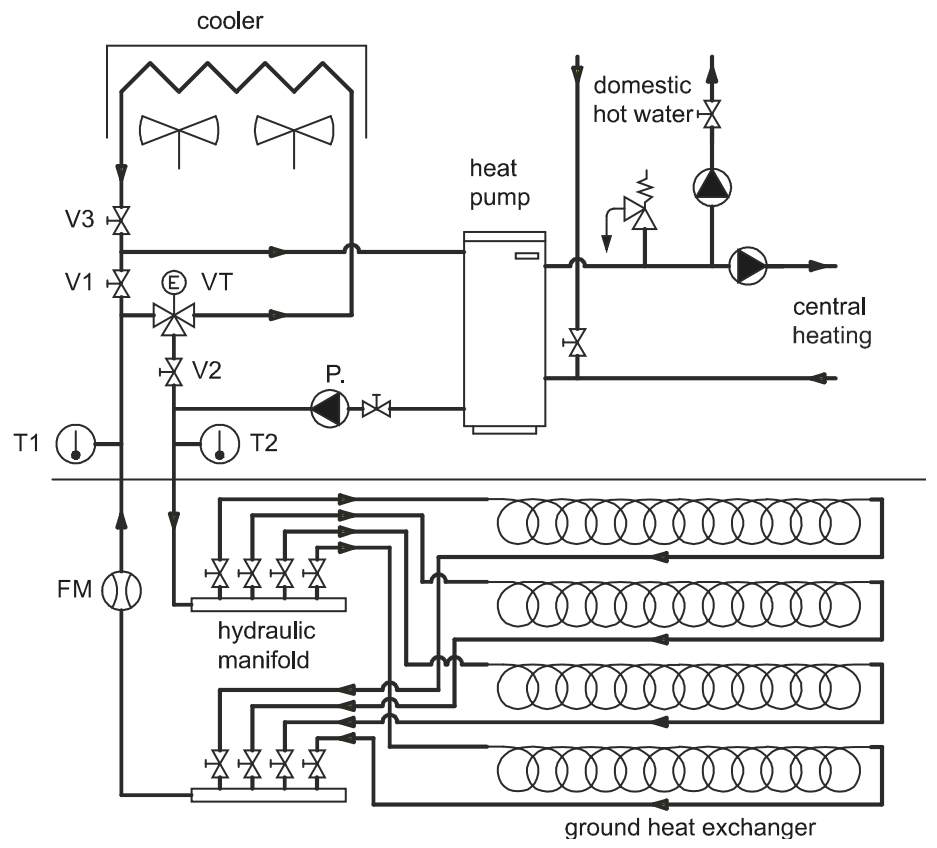

Fig. 3. Hydraulic diagram of passive air conditioning; VT - three-way valve, V1, V2, V3 valves, T1 - temperature of cold heat carrier, T2 - temperature of warm heat carrier returning to ground collector, FM - flow meter, $\mathrm{P}$ - pump

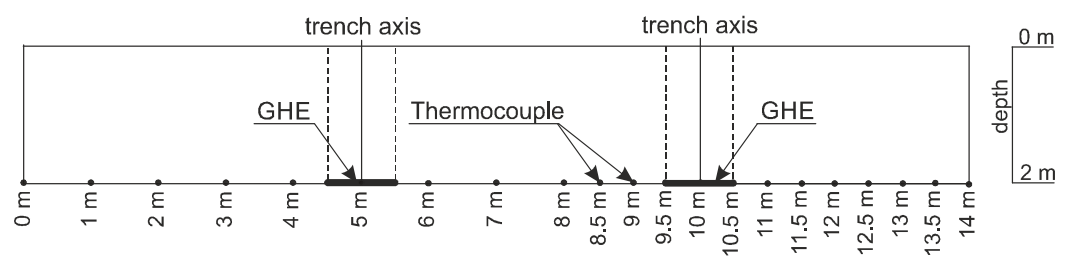

Fig. 4. Thermocouples distribution in the ground; GHE - ground heat exchanger

\section{Results and disscussion}

The ground heat exchanger thermal power was determined by the following equation:

$$
P=\dot{V} \cdot \rho \cdot c_{p} \cdot(T 2-T 1)
$$

where: $\mathrm{P}$ - heat power, $\dot{\mathrm{V}}$ - volumetric flow of glycol, $\rho$ - glycol density, $\mathrm{c}_{\mathrm{p}}-$ specific heat of glycol, T1-T2 - temperature difference.

Figure 5 shows the average inlet temperature T1 and the outlet T2 of the glycol from the heat pump since November 2016 until July 2017. The presented 
data include the period of operation of the heat pump with the air conditioning switched off. It can be seen that the T1-T2 temperature increase of glycol flowing through the ground heat exchanger is on average $4.3^{\circ} \mathrm{C}$. From the beginning of December to the end of May, the temperature of the glycol leaving the heat pump is below $0^{\circ} \mathrm{C}$. The temperature distribution shows that the local minimum average temperature of glycol falls on mid-February. The ground heat exchanger heats the glycol to about $0^{\circ} \mathrm{C}$ in February and to $15^{\circ} \mathrm{C}$ in July (Fig. 5). This significantly influences the efficiency of the heat pump and the heat power from the ground heat exchanger (Fig. 6). The heat output of the lower heat source was measured during operation of the heat pump for at least 30 minutes. It can be read from the graph that the range of the heat output received from the ground is in the range of $-3.2 \mathrm{~kW}$ to $-5.5 \mathrm{~kW}$. The lowest power output is received in February. The heat pump is able to remove up to $-5.5 \mathrm{~kW}$ of heat from the ground and cool the soil during the autumn - winter - spring period, so it is possible to use cold soil in summer to accumulate heat from air cooling in the laboratory.

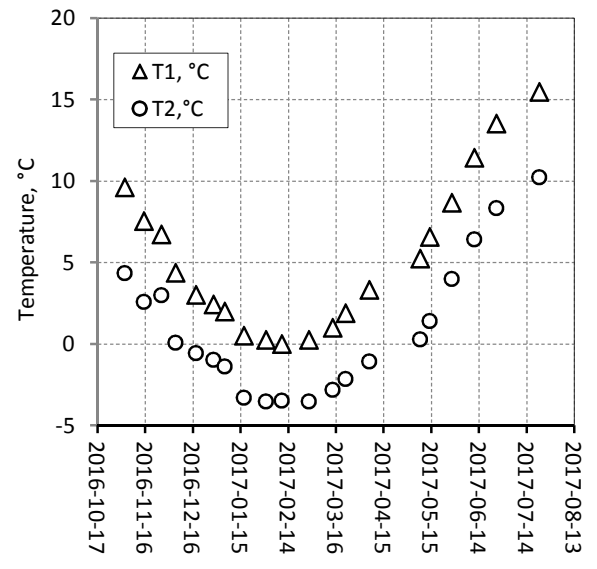

Fig. 5. Inlet temperature $\mathrm{T} 1$ and outlet $\mathrm{T} 2$ of glycol from the heat pump

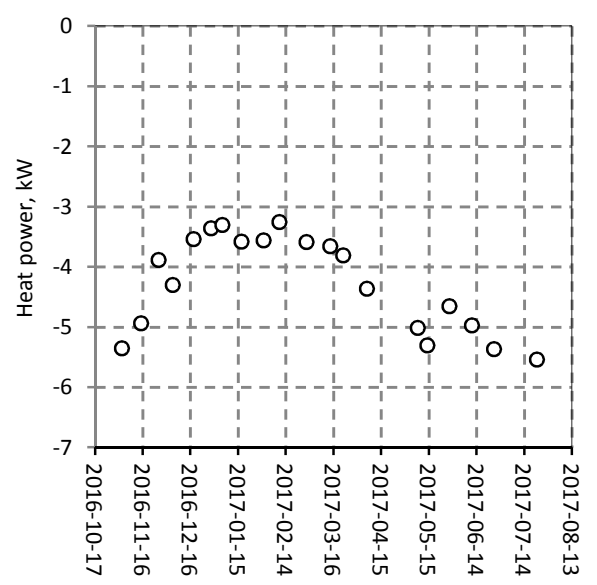

Fig. 6. Heat output of the lower source of the heat pump

The combined heat pump operation in winter and air conditioning in summer increases efficiency of the heat pump and efficiency of the air conditioner. The use of an existing ground heat exchanger of heat pump significantly reduces the investment cost of the air conditioner.

Cooling power measurements included one day of June 22, 2017. The air conditioning was switched on at 8.00, i.e. a glycol circulation pump was started and the fans forcing the air flow through the cooler were switched on. The heat pump was not working. The air temperature in the laboratory at 8.00 was $\mathrm{T}_{\mathrm{amb}}=27.5^{\circ} \mathrm{C}$. When the glycol circulation pump was started, the glycol inlet temperature for the radiator was $\mathrm{T} 1=13.1^{\circ} \mathrm{C}$, while the outlet temperature was $\mathrm{T} 2=15.2^{\circ} \mathrm{C}$. The air conditioner worked seven hours and was off at 15.00. Before 
15.00 , the inlet and outlet temperatures of glycol were $\mathrm{T} 1=14^{\circ} \mathrm{C}$ and $\mathrm{T} 2=16.1^{\circ} \mathrm{C}$, which indicates that the soil was heated and the temperature of the heat carrier returning from the ground increased.

During air conditioning the room air temperature was maintained at about $25-26^{\circ} \mathrm{C}$. The air temperature sensor was placed in the area undisturbed by the cool air from the cooler. After switching off the air conditioning, the temperature in the laboratory raised rapidly up to $30^{\circ} \mathrm{C}$ at 15.30 (Fig. 7). The cooling power vs. time was shown in Fig. 8. The average cooling power of the day was $2.2 \mathrm{~kW}$. As soon as the air conditioner was activated at 8.00 , the cooling power was higher and reached a maximum of $2.7 \mathrm{~kW}$, which is due to the fact that the room temperature at this time was high and amounted $27.5^{\circ} \mathrm{C}$ and the inlet temperature was the lowest and was $\mathrm{T} 1=12.9^{\circ} \mathrm{C}$. The lower inlet temperatures may indicate unsteady heat transfer processes in the ground.

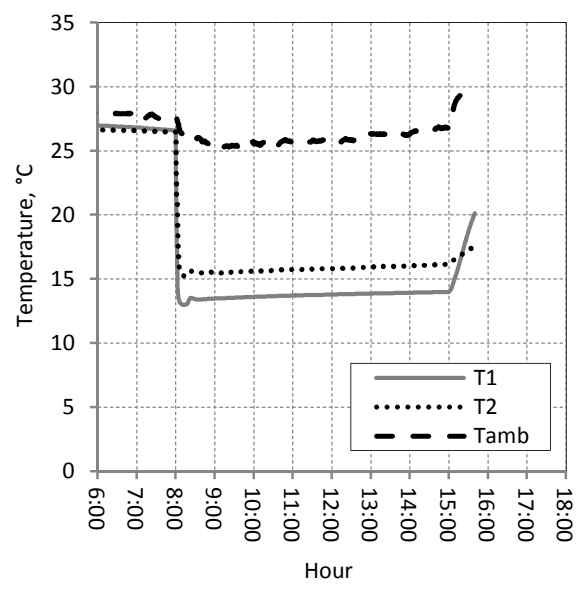

Fig. 7. Measurement of characteristic temperatures; T1 - glycol temperature of the cooler, $\mathrm{T} 2$ - temperature of the glycol outflowing from the cooler, Tamb - ambient temperature

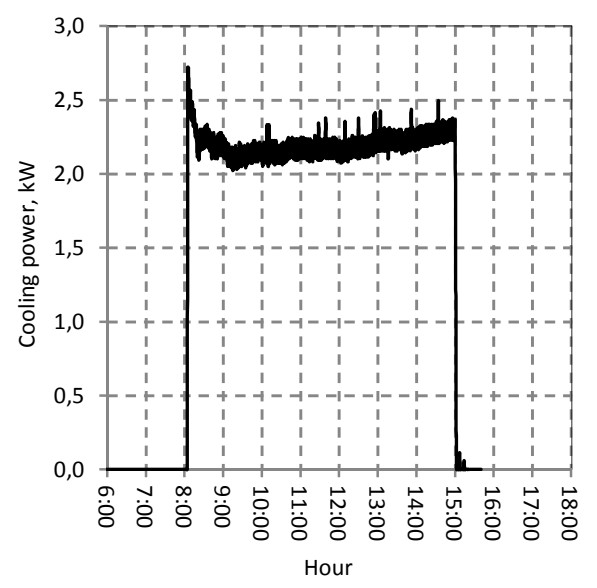

Fig. 8. Cooling power of the passive air conditioning

The day before the air conditioning was off around 16.00, the circulation pump was also switched off, so during the night the heated ground in the near area of the heat exchanger pipe equalized the temperature with the surrounding ground in the far area. The possibility of cooling the glycol in the pipes as a result of low air temperature at night should be excluded, since the average air temperature of the previous night was about $18^{\circ} \mathrm{C}$.

Temperature distributions in the ground were registered from October 15. 2013 to August 26.2014, during the heat pump operation, but before starting the air conditioning. The temperature profile was recorded at the depth of $2 \mathrm{~m}$ and at the length of $14 \mathrm{~m}$ at 1 and $0.5 \mathrm{~m}$ intervals. This profile includes two ground loops of the heat exchanger, one with a $5 \mathrm{~m}$ coordinate and the other with a coordinate 
of $10 \mathrm{~m}$ (Fig. 4). In August soil temperature is the highest. This is due to accumulation of heat in summer. The lowest temperature occurs in February (Fig. 9). Since May, local heating of the ground in the near area of the heat exchanger leveled off because the heat pump is rarely activated. From Fig. 9, it can also be read that the temperature in the near area of the heat exchanger never reaches temperatures below $0^{\circ} \mathrm{C}$. By analyzing Fig. 9 for the purpose of the air conditioning exchanger, it can be concluded that in the period from May to the end of August the average soil temperature rises from $9.1{ }^{\circ} \mathrm{C}$ in May to $15.7^{\circ} \mathrm{C}$ in late August, which is a natural process. The use of additional ground heat exchanger for air conditioning purposes will significantly increase the temperature of the soil.

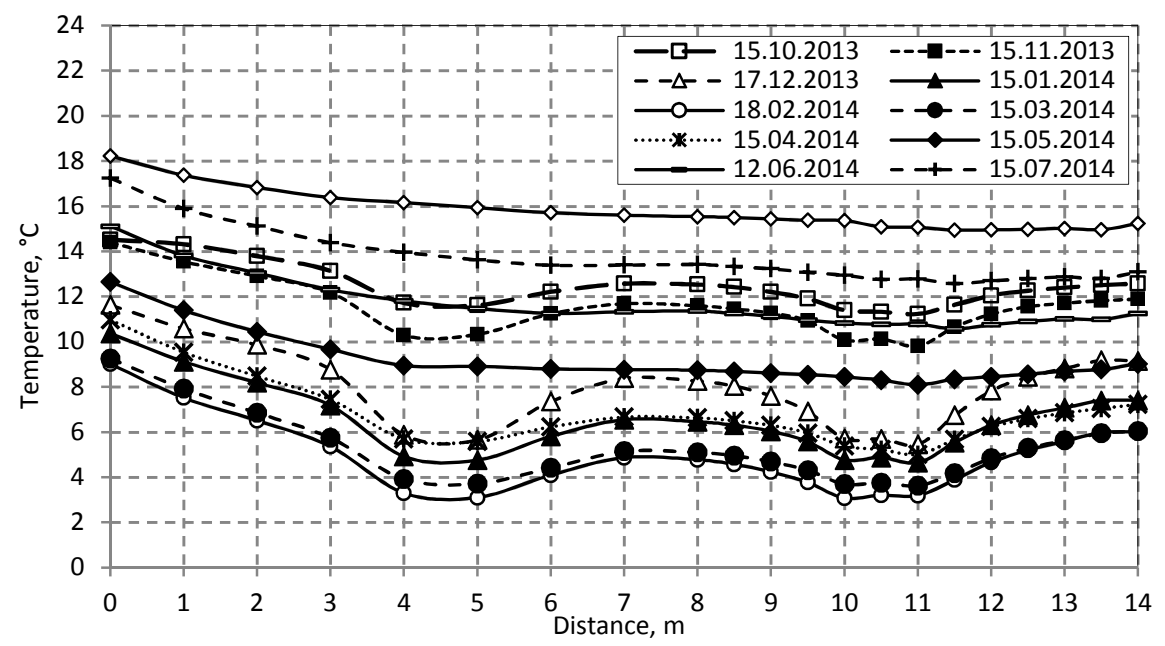

Fig. 9. Soil temperature distribution at the depth of 2 meters near the ground heat exchanger

The presented air conditioning using the ground heat exchanger of the heat pump has advantages and disadvantages in comparison to the compressor air conditioners. The biggest disadvantage is high cost of a ground heat exchanger. In our case we used the existing installation, which resulted in low investment costs. A major disadvantage of GHE is warming the ground during the summer season, which is shown in Fig. 9. The temperature of the ground from May to the end of August increased by $6.6^{\circ} \mathrm{C}$ and there was no air conditioning then. During the operation of the air conditioning and transferring heat to the ground, the temperature rise will be certainly higher: this will result in a significant reduction of the cooling power in late summer months. Another disadvantage of the described air conditioner is the relatively low cooling power of $+2.2 \mathrm{~kW}$ in this case. It is probably possible to increase the cooling capacity to about $+5.5 \mathrm{~kW}$, which is equal to the nominal heat output of the heat pump's lower heat source, but it would then be necessary to increase the heat transfer on the cooler side, increasing the heat transfer surface or increasing the overall heat transfer coefficient. 
The biggest advantage is relatively high EER. The energy consumption of the passive air conditioning is the consumption of electricity needed to supply the circulation pump and two fans. This power was not measured, but assuming the nominal values of the pumps and fans the total power was about $350 \mathrm{~W}$. The coefficient of performance (COP) is the ratio of the cooling power to the power consumed by the air conditioner. By using this definition for passive air conditioning, we get an approximate COP of 6.3.

The heat flux per unit tube length is a very important parameter. For the investigated ground heat exchanger using the heat pump the maximum heat flux reached $9.1 \mathrm{~W} / \mathrm{m}$; the same GHE used for air conditioning obtained maximum heat flux of $4.5 \mathrm{~W} / \mathrm{m}$, which after a few hours decreased to $3.7 \mathrm{~W} / \mathrm{m}$.

\section{Conclusion}

The results of passive air conditioning functioning are presented. The measurements include seven hours of air conditioning on June 22, 2017. The air conditioner was working in the mode of cooling the glycol solution in the ground heat exchanger. The average seven-hour cooling power was $+2.2 \mathrm{~kW}$. This power is about two times too small to effectively cool the air in the considered laboratory. The air temperature in the laboratory during operation of the air conditioner was $25-26^{\circ} \mathrm{C}$. The temperature of the glycol solution entering the cooler was $13-14^{\circ} \mathrm{C}$. The advantage of GHP is a relatively simple construction and reliability as well as high COP, while the biggest disadvantage are investment costs.

\section{Literature}

[1] Gil P., Tychanicz M., Wilk J.: Instalacja skojarzonego wytwarzania ciepła i energii elektrycznej ( $\mu \mathrm{CHP})$ - badania eksperymentalne parametrów energetycznych, Rynek Energii, 5 (2016) 49-57.

[2] Gałek R., Gil P., Grosicki S., Wolańczyk F.: Wymiennikowy zasobnik ciepła w mikrokogeneracji, ZN PRz Mechanika, 31 (2014) 483-490.

[3] Gil P., Wilk J.: Instalacja CHP z silnikiem spalinowym zasilanym gazem drzewnym, ZN PRz Mechanika, 32 (2015) 217-226.

[4] Gil P., Grosicki S., Wilk J.: Możliwości zastosowań metod oczyszczania gazu powstałego ze zgazowania biomasy w generatorze małej mocy, Instal, 12 (2013) 24-28.

[5] Gil P., Wilk J., Tychanicz M., Wielgos S.: Wstępne badania automatycznego kotła na pellet pod kątem wymagań normy PN-EN 303-5: 2012, Rynek Energii, 5 (2017) 74-79.

[6] Gil P., Szewczyk M.: Roczne badania eksploatacyjne parametrów monokrystalicznych modułów fotowoltaicznych w Rzeszowie, Instal, 4 (2015) 22-27.

[7] Florides G., Kalogirou S.: Ground heat exchangers - A review of systems, models and applications, Renewable Energy, 32 (2007) 2461-2478. 
[8] Smith A.: Seasonal subsoil temperature variations, J. Agricultural Research, 44 (1932) 421-428.

[9] Eicker U.: Low energy cooling for sustainable buildings, John Wiley \& Sons, 2009.

[10] Ali M.H., Kariya K., Miyara A.: Performance analysis of slinky horizontal ground heat exchangers for a ground source heat pump system, Resources, 6 (2017) 56.

[11] Naili N., Attar I., Hazami M., Farhat A.: Experimental analysis of horizontal ground heat exchanger for northern Tunisia, J. Electronins Cooling Thermal Control, 2 (2012) 44-51.

[12] Naili N., Hazami M., Kooli S., Farhat A.: Energy and exergy analysis of horizontal ground heat exchanger for hot climatic condition of northern Tunisia, Geothermics, 53 (2015) 270-280.

[13] Gil P.: Roczne wyniki pomiaru sprawności amorficznych kolektorów fotowoltaicznych w Rzeszowie, Rynek Energii, 4 (2015) 75-83.

[14] Strzelczyk P., Gil P.: Wpływ zaćmienia słońca na produkcję energii elektrycznej przez system fotowoltaiczny, J. Civil Eng., Environ. Archit., 34 (2017) 155-164.

\section{BADANIA EKSPLOATACYJNE GRUNTOWEJ POMPY CIEPŁA I KLIMATYZACJI PASYWNEJ}

\section{Streszczenie}

W artykule przedstawiono wyniki badań eksploatacyjnych gruntowej pompy ciepła i pasywnego układu klimatyzacji. Pasywna klimatyzacja wykorzystuje dolne źródło gruntowej pompy ciepła oraz naturalne zimno zgromadzone w ziemi, szczególnie w sezonie letnim. W tekście przedstawiono schemat hydrauliczny i zasadę działania pasywnej klimatyzacji. Celem pomiaru było określenie mocy chłodniczej, charakterystycznych temperatur i rozkładu temperatury w gruncie na głębokości $2 \mathrm{~m} \mathrm{w}$ miejscu zakopania gruntowego wymiennika ciepła. Przedstawiono roczne rozkłady temperatury w gruncie, które bezpośrednio wpływają na uzyskaną moc chłodniczą. Przedstawiono zalety i wady zaprezentowanej pasywnej klimatyzacji.

Słowa kluczowe: klimatyzacja pasywna, pompa ciepła, gruntowy wymiennik ciepła

DOI: $10.7862 / \mathrm{rm} .2018 .12$

Przestano do redakcji: 02.03 .2018

Przyjęto do druku: 10.04.2018 